\title{
The Existence of Legal Protection of Citizens to Government Action in Making Decision of State Administrative
}

\author{
Enny Agustina ${ }^{*}$ \\ ${ }^{1}$ Faculty of Law Kader Bangsa University, Palembang, South Sumatra, Indonesia
}

\begin{abstract}
Government in administrative law considered as a unit, as an authorized body. Therefore, it is authorized to establish action, according to administrative law, and affect the legal circumstances of others, or to carry out legal action (under the civil law) in the meaning of government bodies legally. The dutch literature interpreted administrative with the terms administrative recht with administrative besturen. Besturen has a functional meaning to means the function of governance, and institutional or structural whole organs of government. Bestuur is an environment outside formation of regulations (regulgeving), and judicature (rechtspraak). The data of this research was collected by library research. This research aims to know the form of legal protection for the people to government action based on the concept of State Administrative Law. The result of this research shows that Legal decisions were those which fulfill formal and material requirements. This was based on the presumptive principle of rechtmatig, that was het vermoeden van rechtmatigheid or presumtio justea causa (every decisions issued by the government or the administrative of the state were considered lawful). This principle means that every decision was not revoked, unless there was a vernietiging of the court closely related to the principle of legal certainty (rechtszekerheidbeginsel).
\end{abstract}

\section{Introduction}

Indonesia is a state law, it has described in Article 1 paragraph (3) of the Constitution 1945 said that "the State of Indonesia is a state of law". This is based on the explanation of the Constitution 1945 that the State of Indonesia is based on law (rechtstaat) and it is not based on mere power (machstaat). Therefore, the state did not exercise the activities on the basis of mere power, but based on law. [1]

In Indonesia regulation to the people are undertaken by the government based on the Law of State Administrative. The Law of State Administrative is a set of rules enabling state administrative to carry out the functions, which also protect citizens to attitude of state administrative, and protect the administrative of the state itself. [2]

In conduct a legal relationship (rechtsbetrekking), the legal subject is considered as the owner of the rights and obligations (de drager van de rechten en plichten), such as human (naturlijke persoon), legal entity (rechtpersoon), or position (ambt) legal action based on the ability (bekwaan) or authority (bevoegdheid) it has. In association within the society, many

\footnotetext{
${ }^{*}$ Corresponding author: ennyagustinadua@yahoo.com
} 
legal relationships arise as a result of the legal actions of the legal subject. This legal action is the beginning of legal relations (rechtsbetrekking), that is the interaction between legal subjects that had legal relevance or legal consequences. In order that the legal relationship between the subject of law to proceed harmoniously, equally and equitably, in the sense that every legal subject got their rights and performs the obligations imposed upon them. then the law appears as a rule of play in regulated such legal relationships. [3]

The dynamics of society at this time, supported by technology with fast access to information demanding state administrative able to follow the dynamics of the society. State administrative as the obligatory in carrying out the public functions demanded quickly responsive to problems that occur in society with rapid changes. To achieve the welfare of the society, the government has the position of a ruler with the authority of making regulations of laws, and the position of public servant, duty to administer, implement and serve all affairs and interests of the society. [4]

The ruler is the government (executive ruler) and also the government as administrator (administrative ruler), both are State Rulers (overheid). Government decisions as the government is not perceived directly by the society because a government decision (regeringsbesluit) is always general, principal, abstract, and impersonal. This decision did not concern a particular individual in a particular case. The immediate effect of government decisions as administrators is caused various impacts because administrative beschikking is always individual, casual, concrete, and typical. [5]

Government in administrative law as a unit, as an authorized body. Therefore, authorized to establish action, according to administrative law, and affect the legal circumstances of others, or to carry out legal action (under civil law) the meaning of government bodies legally. The dutch literature interpreted administrative with the terms administrative recht with administrative besturen. Besturen has a functional meaning to means the function of governance, and institutional or structural whole organs of government. Bestuur is an environment outside formation of regulations (regulgeving), and judicature (rechtspraak). [6]

In carrying out the public function of the state administrative lead to various impacts, especially with regard to the rights of the society, included the business entity within which is owned by the society. Between the government as the government and the government as the state administrative took decisions with the same authority, that is "state authority" or public authority. But the government as a government takes government decisions, and as administrators took administrative decisions. In addition, the government's decision was taken the execution or the executive (politieke daad) enforcement of the law and state authority, while the administrative decision was taken as the implementation or realization decision (materialele daad).

According to Tamanaha, the principle of the rule of law means "Government officials and citizens are bound by and act consistently with the law". The principle of legality is the main principle as the basis for the implementation of government and state based on law. Implementation of government and state in state of law based on the law, and the existence of basic human rights guarantees, and the principle of legality is the basis of the legitimacy of government action and guarantee the protection of people's rights. [7]

Based on the description above, the subject matter was formulated in detail as follows: How was the form of legal protection for the people to government action based on the concept of State Administrative Law? 


\section{Objective of the Study}

This research aims to know the form of legal protection for the people to government action based on the concept of State Administrative Law.

\section{Metodology}

This research used Juridical Empirical approach method. And also this research used techniques of collecting legal materials and the data consist of Library Studies (Liberary Research). Analysis of legal materials in this research was done by qualitative and presented descriptively.

\section{Discussion}

\section{Government Legal Actions}

E. Utrecht argues that government action is done in various ways, that is:

1. The act is the administrative of the state itself.

2. The act is a legal subject / legal entity which excluded administrative state, and based on a special relationship, such as a monopoly entity.

3. The act is other legal subject which excluded the administrative state performing the work on the basis of a concession / permit from the government. The work is submitted by the government to a private entity to implement the public interest

4. The acts are other legal subjects who did not include the administrative of a State subsidized by the government, such as an educational foundation.

5. The act is the government together with other legal subjects who did not administrative state, where the two sides are in co-operation, such as the Commercial Industry Bank (where the government is not a shareholder but within the board of directors there are government representatives).

6. The act are foundations established / supervised by the government, such as the Supersemar foundation, the Veteran foundation and so on.

7. The act is a cooperative established / supervised by the government.

8. The acts are State Companies, such as State Electricity Company.

Based on the opinion of E. Utrecht above, then the government action which is a legal action for the implementation of public interest, that is;

1. To impose obligations on the organs to carry out the public interest.

2. Issuing laws that are prohibited or directed to individual citizens to commit necessary deeds (behavior) that are in the public interest.

3. Commandments or provisions that are burdensome.

4. Provide subsidies or assistance to the private sector.

5. Give legal status (rechtstatus) to a person appropriate with wishes, so that the person has rights and obligations.

6. Conduct supervision of private employment.

7. Cooperate with other companies in forms determined for the public interest.

8. Establish agreements with citizens based on matters governed by law. Government action (bestuurshandeling) is an action or deed by government tools (bestuursorgaan) in order to carry out government functions (bestuursfunctie). Actions undertaken by this government there is a legal action (rechtshandeling) and in the form of real action (feitelijkehandeling). Legal action (rechtshandeling) by the nature is an action given rise 
to legal consequences (creating rights and obligations). The act of governmental law was an action taken by the administrative state body or state administration officials in carrying out government affairs. Government actions had elements, that is:

1. The act is committed by the government apparatus in capacity as a ruler or as well as a tool of government (bestuurs-organen) with own initiative and responsibility;

2. The act is carried out in order to carry out the function of government;

3. The act is intended as a means to cause legal consequences in the field of administrative law;

4. The action concerned is done in the framework of maintaining the interests of the state and the people. Government legal action has elements, as follows [8] :

Such action was carried out by the government apparatus in the position as ruler or as a tool of government (bestuursorgaan);

1. Actions were implemented in the framework of perform the government functions (bestuursfunctie);

2. The act was intended as a means of cause the legal consequences (rechtsgevolgen) in the field of administrative law;

3. Acts committed in the framework of the maintenance of the public interest;

4. Actions were made on the basis of the norms of government authorities;

5. The act was oriented toward a specific purpose based on law.

\section{Types of the Government Legal Actions}

The act of administrative state did not always result in legal consequences for society, since it is non juridical (there is no legal effect), but there are administrative state actions that had legal consequences (legal actions).

There are four kinds of legal acts (rechtshandelingen) state administration, that is [9]

1. Determination (beschikking, administrative discretion);

2. Plan;

3. Occupational Norms (concreto normgeving);

4. Pseudo-legislation (pseudowetgeving).

The legal action carried out by the government in the administrative law of the state, that is [10]

1. Government legal action / state administration based on civil law or private law. Two opinions arise about permission of administrative state to establish legal relationship based on private law, that is:

a. State administration in perform the government duties did not use private law, because the nature of private law is a legal relationship governing the relationship of the volition on both sides, as well as individual. Administrative state considered as a part of public law, as well as a law to allow action on the part of one part

b. State administrative used private law. However, it is to solve a specific problem which in the field of administrative state has available the rules of public law.

2. Act of legal administrative state based on public law there are two kinds, that is:

a. Public legal acts one is the deed of public law which is the volition of one party from the government, did not involve the society.

b. Manufacture law of public secondary. The government legal actions exist based on public law (Stroink), and under private law.

Actions based on public law (publiekrechttelijke handeling) constitute governmental actions based on public law (administrative law). Public legal action exist unilaterally (eenzijdig publiekrechtelijke handeling), and of two or more parties (meerzijdik 
publiekrechtelijke handeling). This one-sided public legal action perpetrated by government equipment is called beschiking ", which in Indonesian is called by term or decision", while two-or more-sided public legal actions, such as government employment contracts, or "kortverband contract" (a short-term employment agreement between the private and the government). [11]. Public legal action that both square and rectangular categorized into three parts, that is:

a. The act of making a decision (beschikking); Unilateral public legal action (rectangular one) was divided into three, that is:

1. Unilateral - concrete - individual;

2. Unilateral - concrete - general; and

3. More than one administrative state office - concrete-general.

b. The act of regulating (regeling), and the legal actions of the government in the field of public law also unilateral (one-sided) and the rules were issued in a general-abstract way. Legal action in the form of government regulations, presidential regulations, ministerial regulations, governor regulations and others.

c. Material action (material daad). Acts committed in the form of material acts are committed to the public interest involved two or more parties, that is government and civil (private) as well as other parties.

These public legal actions, for example, make employment agreements; created memoranda of understanding, vortex contract, and so on. Government action in the form of private law was a government action in the position of not as a government. This act as a representative of a legal entity (lichaam) and it was not a duty for public affairs, so actions were based on the provisions of private law (civil). If the government acts in the quality as a government, then the public law was applicable and did not act.

The decision of the administrative state was a general and abstract understanding, and in the realization has a different form, but all decisions of the administrative of this country had the same characteristics. Understanding the decision of administrative state was important, because this decision has consequences in a positive law that results in a legal effect. So in test (toetsingsgronden), case of problems resolved properly and correctly under the law. Decisions were made on the basis of a clear and decisive law called a bound decision (gebonden beschikking) tested by a judge on the basis of statutory regulations, and an unequivocal decision (implied) was called a free decision (vrije beschikking) tested by a judge based on the general principles of good governance.

The purpose of this decision has two possibilities, that is addressed to (naar binnen gericht), is a decision into force into the administrative environment itself, and addressed outside (naar buiten gericht), which applied to citizens or civil legal entities. Based on the division, there are two types of decisions; internal decisions (interne beschikking) and external decisions (externe beschikking). [12]

Based on the nature of the government's decision was divided into two. Firstly, the government's decision in the sense of the executive was a decision, that is general, principal, abstract and impersonal-regardless of an individual, and not in a particular case (the form was the rule), the executive / executive decision (politieke daad) in the context of law enforcement and state authority. Secondly, the government's decision as state administrative was an individual, casuistic, concrete or real decision (the form was a decision, beschikking), was a materiale daad decision. Legal products of government administrative bodies / officials in the form of documents contained concrete, individual, and final determinative materials in administrative law are called decisions (beschikking). [13]

The terms of the decision material were:

1. Created by government organs authorized. 
2. Did not contain deficiencies or legal defects.

3. Did not contrary to the basic rules.

Formal decision requirements were:

1. Created based on procedures specified in the basic rules.

2. Given the prescribed form

3. Timing is valid.

4. Announcement (bekendmaking) or notice to the affected decision.

5. Signature (ondertekening) authorized officials

Between administrative state decisions and regulations there are differences. Decisions were made in order to solve concrete, casuistic issues, addressed to specific individuals / individuals. The rules were made for abstract things that had not known before, general and which may come later. The difficulty of distinguishing between decisions and regulations, when the rules were einmalig-a rule made to solve a concrete case and after the completion was done then the rule stops by itself without revoked, for example the regulation of a university governing the procedure of inter-rector election due to the rector the former is unable to remain or die.

\section{Conclusion}

Legal decisions were those that fulfill formal requirements and material requirements. This is based on the presumptive principle of rechtmatig, that is het vermoeden van rechtmatigheid or presumtio justea causa (every decisions issued by the government or the administrative of the state were considered lawful). This principle means that every decision was not revoked, unless there is a vernietiging of the court closely related to the principle of legal certainty (rechtszekerheidbeginsel). The amendment or revocation of a decision applied the principle of contrarius actus similiter fit (procedures and conditions of change or revocation of decisions were the same as the procedures and conditions of manufacture), which related to the principle of authority (bevoegdheidsbeginsel). The nature of the legal norms of state administrative decisions was individual and concrete, and within a set of legal norms was the closing norm.

\section{References}

1. A. Jum, State Administrative Law. (Graha Ilmu: Yogyakarta 2012).

2. A. S, Prajudi. State Administrative Law. Revised Edition; Series Library Science State Administrative VII Jakarta, (Ghalia Indonesia 1994).

3. D. Darumurti, Power of Government Discretion. (PT. Citra Aditya Bakti: Bandung 2012).

4. E. L. Paulus, State Administrative Law and Power. (Salemba Humanika: Jakarta 2013).

5. P.M. Hadjon, et al. Introduction to Indonesian Administrative Law. (Gadjah Mada University Press: Yogyakarta 2002).

6. J. Murtir, State Administrative Law. (Total Media: Yogyakarta 2012).

7. J.D. Muh, State Administrative Law. (Unhalu Press: Kendari 2011).

8. K. Eny, Legal Bases of State Administration and Good Public Administration Association. (UNY Press: Yogyakarta 2011).

9. S.F.Marbun, State Administrative Court and Administrative Efforts in Indonesia. (FH UII Press: Yogyakarta 2011).

10. ----------. State Administrative Law I. (FH UII Press: Yogyakarta 2012). 
11. H.R. Ridwan, State Administrative Law. Revised Edition, (PT. RajaGrafindo Persada: Jakarta 2011).

12. R. Juniarso and A. Sodik Sudrajat, State Administrative Law and Public Service Policy. (Nuance: Bandung 2012).

13. Ridwan, Three Dimensions of Law Administrative and Administrative Court. (FH UII Press: Yogyakarta 2009). 